\title{
A reform agenda for improving the delivery of ALMPs in the MENA region
}

\author{
Diego F Angel-Urdinola* and Rene A Leon-Solano*
}

\author{
* Correspondence: \\ dangelurdinola@worldbank.org; \\ rleonsolano@worldbank.org \\ The World Bank, Washington, DC, \\ USA
}

\begin{abstract}
Given the labor market challenges that countries in the Middle East and North Africa (MENA) region are facing (notably high unemployment, prevalence of skills mismatches, low labor market mobility, and lack of formal employment networks), Active Labor Market Programs (ALMPs) could be a relevant policy instrument to assist unemployed individuals find jobs. This study first introduces a conceptual framework for ALMPs and describes their overall impact on employment outcomes. The study then reviews the provision of ALMPs in a selected group of countries in the MENA region, with a focus on public provision through existing public employment agencies. The study also presents the results of some of the few available robust evaluations of AMLPs the region, in a context where information about program effectiveness and efficiency is largely lacking. Finally, the study identifies key challenges in the delivery of publicly provided ALMPs in MENA countries, namely poor administrative capacity, system fragmentation, lack of governance and accountability, regulation bottlenecks, and flaws in program design. To address these challenges, the study proposes a reform agenda based on a fourpillar policy framework: (i) develop results-based Public Private Partnerships (PPPs); (ii) promote systems and program integration; (iii) develop results-based monitoring and evaluation (M\&E) frameworks; and (iv) promote entrepreneurship/self-employment, on-the-job training and life skills training among job seekers.
\end{abstract}

JEL codes: J20, J30, J40, J50

Keywords: Labor policy; labor markets; unemployment; training; labor regulation; school-to-job transition

\section{Introduction}

The study draws on data collected through surveys administered to public employment agencies in selected Middle East and North Africa (MENA) countries to identify key constraints and options for reforming publicly provided ALMPs.

Unemployment rates in MENA are among the highest in the world, and the region has a large share of untapped human resources. Female labor force participation, at 25.4 percent in the Middle East and 28.1 percent in North Africa, is significantly lower than the world average of 51.6 percent (World Bank 2013). ${ }^{1}$ Youth unemployment is higher in the Middle East (19 percent) and North Africa (25 percent) than in any other developing region. At the same time, population growth in MENA is also among the highest in the world, with a demographic transition in which the youth bulge (ages

\section{Springer}

๑ 2013 Angel-Urdinola and Leon-Solano; licensee Springer. This is an Open Access article distributed under the terms of the Creative Commons Attribution License (http://creativecommons.org/licenses/by/2.0), which permits unrestricted use, distribution, and reproduction in any medium, provided the original work is properly cited. 
15-24) accounts for about 30 percent of the overall population, compared to 18 percent worldwide (World Bank 2013).

Although unemployment rates in MENA are high and rising, employers in the region are still struggling to fill vacancies primarily due to a shortage of candidates with the relevant qualifications and skills (World Bank 2013). Indeed, more than half of employers in MENA identify skills mismatches as a major constraint to doing business and to firm growth, according to enterprise surveys. This percentage is the highest among developing regions (World Bank 2013). A combination of inadequate skills and lack of information about existing vacancies is contributing to critical labor market failures that restraint employment mobility. This is confirmed by available data from employment agencies throughout the region suggesting that thousands of vacancies are not being filled, despite the existence of thousands of individuals who are both willing and able to work (see Angel-Urdinola et al. 2013 and Belghazi 2012).

Available evidence also indicates important constraints to labor market transitions in MENA (World Bank 2013). Recent work shows that while the school-to-work transition in developed countries generally takes less than two years (measured as the difference between the age at which 50 percent of the population has left education and the age at which 50 percent has found employment), in many MENA countries it takes over five years (World Bank 2013; Angel-Urdinola and Semlali 2010). Moreover, private and public formal employment networks play a limited role in labor intermediation (Gatti et al. 2012).

In a context where skills mismatches prevail, unemployment soars, information about job opportunities is asymmetric, and there seems to be vacancies that cannot be filled, ALMPs could help to enhance labor mobility and improve job matching. Available evidence suggests that ALMPs do not have a good track record of improving labor market outcomes in developing countries. However, poor performance of ALMPs should not lead to the conclusion that they are not a relevant policy instrument to address labor market challenges. Instead, the causes of their apparent failure need to be closely examined. Existing analytical studies and evaluations suggest that ALMPs in developing countries suffer from poor design and implementation as well as from inappropriate governance and accountability arrangements that reduce incentives to respond to the needs of job seekers and employers (Betcherman et al. 2004; Card et al. 2010; Kuddo 2009; Rodriguez-Planas and Benus 2010).

This study offers a comprehensive look at the problems facing publicly provided ALMPs in a selected group of MENA countries, takes stock at some initiatives that seem to have had positive results in the region, and proposes a policy reform agenda to improve effectiveness and delivery of ALMPs in the region. Admittedly, ALMPs should not be seen as substitutes for private-led employment creation or as a solution to the many structural constraints of the region's labor market, such as stagnant labor demand, low productivity, low competitiveness, and high informality. However, if well designed and effectively delivered, ALMPs could be a mechanism for addressing high unemployment rates, all while providing the region's population with some immediate and concrete results.

\section{ALMPs and public employment services: an overview}

The two overarching objectives of ALMPs are to enhance employability and promote job creation. ALMPs are considered "active" programs because beneficiaries are 
required to engage in an activity ("activation") in order to receive a service or financial benefit. In this respect, ALMPs differ from "passive" measures such as unemployment insurance/assistance, which are designed to mitigate the financial hardship of unemployment. ALMPs can help correct employment barriers that can arise from the existence of skills mismatches, insufficient labor demand, and information asymmetries (Table 1). ALMPs have been widely used by governments around the world to lessen the impacts of economic downturns by providing both employers and employees with incentives to participate in the labor market (see Kuddo 2009).

International experience shows that the impact of ALMPs on labor market outcomes is positive, but modest. While many ALMPs have effectively addressed market failures in countries with very different labor market challenges, many others have not succeeded in improving beneficiaries' livelihoods. Using meta-analysis, Card et al. (2010) reviewed a set of impact evaluations of ALMPs for a sample containing 199 separate "program estimates" (i.e., estimates of the impact of a particular program on a specific subgroup of participants). The estimates were drawn from 97 studies conducted between 1995 and 2007. The authors found that (a) job search assistance programs are likely to yield positive impacts on employment outcomes, that is, employment levels and wages; (b) training programs yield relatively positive impacts on beneficiaries' employment outcomes in the medium term, but often have insignificant or negative impacts in the short term; and (c) the impact of public works programs on employment outcomes is limited. Indeed, the efficiency of ALMPs depends largely on their design, as well as on the country's institutional capacity to provide services continuously on a national scale (Angel-Urdinola et al. 2010; World Bank 2013).

Program costs for ALMPs vary widely, and some ALMPs are more cost-effective than others. ALMPs that seek to encourage labor demand in times of economic downturn generally involve providing subsidies to either firms or workers. The amount of the transfer (and thus total program cost) depends largely on the country's economic and political context as well as on its labor market institutions, including wage levels. Training programs also have variable costs, which reflect the training's length, content, and necessary equipment. As a result, policy makers need to pay special attention to the cost-effectiveness of ALMPs. For example, results from Romania show that training programs are more cost-effective than employment services and public works programs (Rodriguez-Planas and Benus 2010). The authors found that training programs have, on average, high placement rates after program completion (above 40 percent) and low percapita placement costs (about $\$ 2,000$ per beneficiary). In contrast, public works programs have, on average, low insertion rates after program completion (approximately 12 percent) and are 10 times more costly on a per-capita basis than training programs.

Table 1 Selection of ALMP Type by Objective and Employment Barrier

\begin{tabular}{lll}
\hline Barrier to employment & Type of ALMP & Program objective \\
\hline Skills mismatches & Training (on the job, in class), activation. & Enhance employability \\
\hline Information asymmetries & $\begin{array}{l}\text { Intermediation services, job search } \\
\text { assistance, counseling. }\end{array}$ & $\begin{array}{l}\text { Enhance employability/ } \\
\text { promote job creation }\end{array}$ \\
\hline Insufficient labor demand & $\begin{array}{l}\text { Wage subsidies, public works programs, } \\
\text { self-employment, work sharing and } \\
\text { short work. }\end{array}$ & Promote job creation \\
\hline
\end{tabular}




\subsection{Public employment agencies}

Public employment agencies are the institutions responsible for delivering public employment services (PES). These agencies deliver employment services free of charge to job seekers (both the unemployed and job changers) as well as to employers and the inactive population. Services provided by public employment agencies include (a) information services, ranging from ad hoc information and referrals for job seekers to job brokerage services for employers; (b) individual case management services, such as intensive counseling and guidance, job search assistance, and personalized action plans; and (c) active and passive programs, including opportunities for work, training, and other forms of assistance such as unemployment insurance.

In developed countries, PES have been instrumental in helping unemployed workers find jobs. This is the finding of most experimental studies carried out in Canada, the Nordic countries, the United Kingdom, and the United States. For example, a study in Denmark found that workers who received personalized job search assistance, career counseling, and regular check-up meetings at the local public employment agency had a 30 percent higher rate of employment than a control group that did not receive these services (Graverson and Van Ours 2007). An evaluation of a similar package of services in four regions of Sweden also found that participants had a 30 percent higher employment rate than a control group and, moreover, that the effects were most positive for job seekers aged 45 years or older (Hägglund 2009). In contrast, individual case management services were found to be ineffective for young workers (in Canada and the Netherlands) and in cases of mass layoffs (in Canada) (see Rodriguez-Planas 2007 for an overview). In Romania, evidence suggests that both intermediation services and small-business assistance programs can help the unemployed go back to work, but that of these two types of PES, intermediation services have higher placement rates (Rodriguez-Planas 2007).

In developing countries, the effects of PES on labor market outcomes have been found to be less positive. Many developing countries have large informal sectors and face low economic growth, conditions under which PES can play only a limited role, as these programs are geared primarily toward wage employment (Betcherman et al. 2004). In general, the success of PES depends largely on program design and implementation as well as on institutional capacity of the public employment agency. Indeed, successful PES are characterized by a combination of good design, implementation, and governance features that include coordination with the private sector, quality assurance and accreditation mechanisms, and solid monitoring and evaluation. Unfortunately, these features are often lacking in PES offered by developing countries (Angel-Urdinola et al. 2010).

Modern PES play an important activation role. The functions of PES have changed over the years, partly because of the gradual disappearance of lifelong jobs and an increasing need for job mobility. In the past, the role of PES was confined to job intermediation and unemployment insurance. Today, many PES are helping individuals take ownership of their own job search and human capital development-the so-called activation agenda. Activation policies encourage job seekers and other vulnerable groups to become more active in finding work and improving their employability, including investing in their own skills (see, for example, OECD Organisation for Economic Co- 
operation and Development 2007). ${ }^{2}$ Good activation policies seek to improve beneficiaries' personal, social, and vocational skills and/or help them plan, design, and implement individual professional plans. ${ }^{3}$

Private sector involvement in the provision of PES has been a key feature of successful PES reform (Kuddo, Kuddo 2012; Finn 2011). Private agencies are often more efficient and effective than the public sector in the provision of PES, as they can provide services to smaller, targeted segments of the labor market and are better positioned to reach out to potential employers (Kuddo 2012). In general, public employment agencies serve individuals with lower skills and limited education, while private employment agencies serve the better-skilled and better-educated. ${ }^{4}$

\section{Provision of ALMPs in MENA}

This section provides an overview of provision of ALMPs in a selected group of MENA countries, with a focus on public provision. While some MENA countries (Tunisia and to some extent Morocco) still provide ALMPs primarily through the public sector, others (such as Lebanon, Egypt, and Jordan) actively involve the private sector in the provision of training, job brokerage, and other labor market services. For instance, according to a recent World Bank study, there are 45 licensed private employment agencies in Jordan and 54 in Egypt. ALMPs are also subcontracted to external providers in Lebanon (Angel-Urdinola et al. 2013).

\subsection{Private provision}

There is very little data or analysis of privately-provided ALMPs in MENA countries, despite the fact they are very common in the region. The work of Angel-Urdinola et al. (2010) is a first attempt to gather information on privately provided ALMPs in the MENA region, with a focus on North Africa. Based on data collected in 2009-10, the authors compiled an inventory of privately provided ALMPs across nine economies in the region: Morocco, Algeria, Tunisia, Egypt, Lebanon, Syria, Jordan, West Bank and Gaza, and Yemen. Information about 17 programs was collected in Egypt, where private provision of ALMPs is very common, followed by Morocco (14 programs), West Bank and Gaza (13 programs), Lebanon (10 programs), and Jordan (8 programs).

Training is the most common ALMP offered by private providers in MENA countries. According to Angel-Urdinola et al. (2010), private providers in the region offer primarily traditional in-class training, which accounted for about 91 percent of all interventions included in the inventory. Other employment services, such as entrepreneurship training, intermediation, and self-employment promotion, together constituted less than 9 percent of all privately provided ALMPs. According to the authors, most of the training programs in the inventory focus solely on the provision of hard skills (64 percent) and are conducted in classrooms (71 percent). Very few privately provided training programs surveyed as part of this study provide on-the-job training, soft-skills training, or intermediation services, even though international best practices show that these are critical to improve the employability and employment chances of unemployed individuals. University graduates in urban areas are the main beneficiaries of privately provided ALMPs in MENA countries (Angel-Urdinola et al. 2010). 


\subsection{Public provision}

While publicly provided ALMPs are more diverse than those provided by the private sector in terms of types of programs, training remains the most popular ALMP provided by the public sector in MENA countries. Angel-Urdinola et al. (2013) conducted the first survey of publicly provided ALMPs in a selected group of MENA countries. The authors surveyed a total of 33 ALMPs that were implemented in 2010 by the public employment agencies of seven countries in the region: Egypt, Jordan, Lebanon, Morocco, Syria, Tunisia, and Yemen.

The study found that the majority of these ALMPs focused on enhancing the employability of program participants, with training being the most widely used intervention (Figure 1). In fact, 30 percent of the ALMPs surveyed for the study focused on vocational training. Morocco and Yemen did offer packages that combined in-class training with other services such as wage subsides and start-up incentives. In Yemen, only one ALMP was implemented by the public employment agency in 2010, but this program included several components such as training, labor intermediation, direct job creation, and out-of-work income support. Other ALMPs that were implemented by the public employment agencies that participated in this study included direct job creation through public works (15 percent of all programs in the inventory), start-up incentives (9 percent), and programs targeted to persons with disabilities (3 percent).

Employment-incentive programs, mainly wage subsidies, have a prominent role in Jordan, Morocco, and Tunisia. These programs encourage potential employers to hire labor. For example, a program in Jordan subsidizes 100 percent of the employee's contribution and 50 percent of the employer's contribution to social security for a period of two years. In Tunisia, on-the-job training programs targeting primarily first-time job seekers subsidize part of social security contributions and wages for a period of one year (renewable), thus decreasing labor costs and promoting job creation.

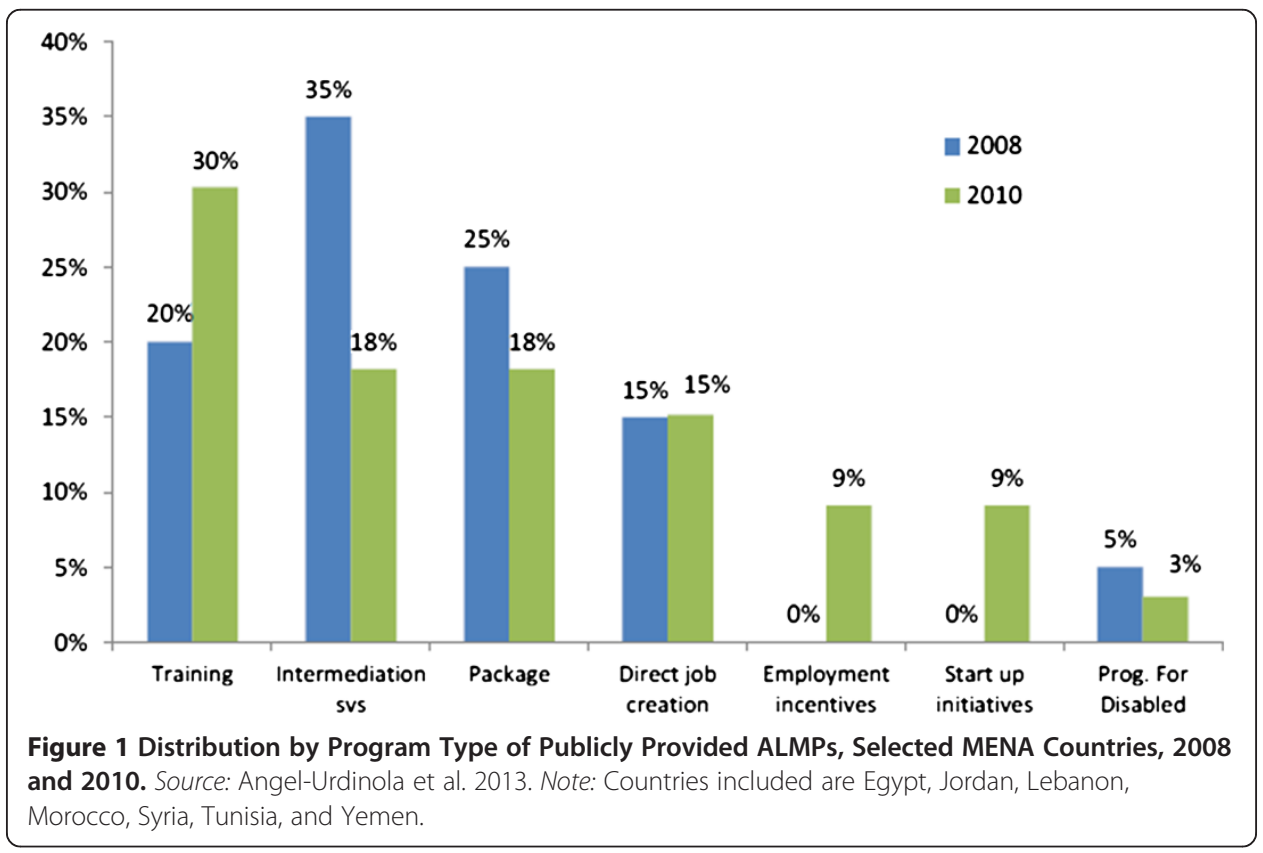


Almost half of ALMPs delivered by public employment agencies in MENA countries (47 percent) target high-skilled unemployed individuals, notably university graduates who are first-time job seekers. Considering that high-skilled youth face higher than average, and increasing, rates of unemployment, it is no surprise that publicly provided ALMPs target this segment of the population (World Bank 2013). ${ }^{5}$ Nevertheless, there are some publicly provided ALMPs that benefit individuals living in rural areas and target the low-skilled unemployed, women, and other vulnerable groups. While most publicly provided ALMPs are open to both men and women, women are radically underrepresented, except in Tunisia (Angel-Urdinola et al. 2013). This could be due to many factors, including lack of schedule flexibility and child care constraints.

Most public employment agencies in MENA countries offer intermediation services. Many countries in the region have developed job banks that can be accessed electronically, using home computers or computers in local employment offices or other public premises. Employers can enter their vacancies, and the job seeker can upload a curriculum vitae $(\mathrm{CV})$ to the database with the help of a placement officer or independently. Despite their availability, intermediation services are not widely used by either employers or employees. This is partly because public employment agencies in the region display limited capacity to do effective matching (Angel-Urdinola et al. 2013). According to the authors, this is true to a large extent, as public employment agencies in the region generally do not have a systematic way (or staff dedicated) to match registered unemployed to available vacancies.

\section{Challenges for an effective public delivery in MENA countries}

This section briefly describes the main obstacles to the effective and efficient delivery of publicly provided ALMPs in a selected group of MENA countries. The analysis, which leverages the findings of Angel-Urdinola et al. (2013), focuses on institutional and operational challenges. Other factors affecting the performance of the region's labor market, such as stagnant labor demand, skills mismatches, and demographics, are beyond the scope of this study.

\subsection{System and program fragmentation}

Countries in the region have different institutional arrangements for administering publicly provided ALMPs. For example, in Egypt, Jordan, and Yemen, these programs are administered directly by the Ministry of Labor, through a specialized department within the ministry. On the other hand, in Lebanon, Morocco, Syria, and Tunisia, these programs are administered by independent and autonomous public employment agencies that are supervised by the Ministry of Labor.

The delivery of publicly provided ALMPs, and especially of training services, is typically fragmented. Many government entities other than national public employment agencies are involved in the provision of publicly provided ALMPs. For example, Egypt has 1,237 vocational training centers that are affiliated with 27 different ministries and that operate somewhat independently throughout the country's 19 governorates. At the same time, the Ministry of Education administers around 1,600 technical and vocational schools, while the Ministry of Higher Education manages 47 middle technical institutes. 
The fragmentation in the delivery of vocational education and training leads to duplication and inefficiencies. In Tunisia, publicly provided ALMPs, notably public works and employment programs targeted to vulnerable groups such as disabled people, are often delivered by different ministries, namely Vocational Training and Employment, Regional Development, and Social Affairs. Due to poor inter-ministerial coordination and lack of a single registration mechanism, many of these programs are redundant and provide incentives for individuals to participate in several programs, even concurrently, thereby promoting welfare dependency (Belghazi 2012). Furthermore, there is little coordination between training programs and the needs of the labor market. Curricula are outdated and are not reviewed frequently, and many training centers provide predesigned training courses that do not necessarily meet the needs of the private sector (Angel-Urdinola and Semlali 2010).

Moreover, program fragmentation is also common. Many MENA countries have developed a plethora of small and independent employment programs that target various groups and that are implemented at different geographic levels by different stakeholders. However, these programs lack complementarity and coherence, thus leading to redundancy and inefficiencies. For example, before 2009, the public employment agency in Tunisia offered 41 employment programs, many of which were largely redundant and duplicative. Upon completing one program, many individuals simply moved to another, and some even enrolled in more than one program simultaneously (Belghazi 2012). Tunisia just recently consolidated all of its employment programs into four, a reform that is expected to increase program effectiveness and efficiency.

\subsection{Limited administrative capacity}

An important factor contributing to the success of publicly provided ALMPs is the institutional capacity of the national employment agencies. This includes the number and qualifications of their staff at both national and regional levels, their geographic coverage, the legal framework in which they operate, and their budget allocations. The amount of resources available for financing ALMPs has often been used as a proxi for service delivery capacity. Of course, this proxy has a lot of caveats as available resources may or may not be used effectively. Nevertheless, higher expenditures on ALMPs are often associated with higher program/service coverage, better quality of staff, and more resources for proper monitoring and evaluation (Kuddo 2009). There is wide variation in spending on publicly provided ALMPs across MENA countries. According to available data, in 2010-11, Tunisia spent 0.80 percent of gross domestic product (GDP) on ALMPs, Morocco 0.10 percent, and Lebanon 0.04 percent. In contrast, across the European Union (EU), a total of 256 billion euros, or 2.2 percent of EU-27 GDP, was spent on ALMPs in 2009-a year of economic downturn (Kuddo 2012).

Public employment agencies (PEA) in MENA countries are generally understaffed. The workload of caseworkers, or those PEA staff in direct contact with clients, is critical for the effective and efficient provision of publicly provided ALMPs. Available data from 2009 show wide variations in levels of staffing among the seven MENA countries that participated in the study (Angel-Urdinola et al. 2013). The highest staff caseload was reported in Syria, with more than 14,000 registered job seekers per caseworker. Next was Morocco, with over 1,500 job seekers per caseworker, followed by Lebanon, with over 1,200 (Table 2). Of the total PEA staff in Syria, Lebanon, and Jordan, fewer 
Table 2 Numbers of Unemployed, Registered Job Seekers, and Public Employment Agency Staff, Selected MENA Countries, 2009

\begin{tabular}{lccccc}
\hline Country & $\begin{array}{c}\text { Number of } \\
\text { registered } \\
\text { job seekers } \\
\text { (thousands) }\end{array}$ & $\begin{array}{c}\text { Total } \\
\text { number of } \\
\text { PEA staff }\end{array}$ & $\begin{array}{c}\text { Number of PEA } \\
\text { staff in contact } \\
\text { with job seekers } \\
\text { and employers }\end{array}$ & $\begin{array}{c}\text { Staff } \\
\text { caseload }\end{array}$ & $\begin{array}{c}\text { Ratio of frontline } \\
\text { counselors to } \\
\text { total PEA staff (\%) }\end{array}$ \\
\hline Egypt, Arab Rep. & 895.1 & 1,600 & 1,550 & 577 & 97 \\
\hline Jordan & 28.0 & 133 & 63 & 444 & 47 \\
\hline Lebanon $^{c}$ & 12.2 & 32 & 10 & 1,222 & 31 \\
\hline Morocco & 517.0 & 547 & 343 & 1,507 & 63 \\
\hline Syrian Arab Republic & $1,703.8^{\text {d }}$ & 397 & 120 & 14,199 & 30 \\
\hline Tunisia & 281 & 1,271 & 1052 & 267 & 82 \\
\hline Yemen, Rep. & - & - & 60 & - & - \\
\hline
\end{tabular}

Source: Angel-Urdinola et al. 2013.

Note: $-=$ not available.

a. Based on latest available labor force survey data.

b. Average number of registered unemployed per PEA staff person in contact with job seekers.

c. Beirut only.

d. Public sector only, including individuals queuing for civil service and other public sector jobs.

than half are caseworkers. Within the European Union, the average staff caseload is around 1:150, while the ratio recommended by the ILO is even lower, at 1:100. ${ }^{6}$ Therefore, in many countries in the MENA region, the number of PEA staff, in particular caseworkers, is inadequate for the provision of effective and personalized mediation services. $^{\text {? }}$

With few exceptions, public employment agencies in the MENA region play a limited role in job matching. In Egypt and Lebanon (Beirut only), however, public employment agencies are quite active in registering job vacancies (Table 3). On the other hand, the job-seekers-to-vacancy ratio is relatively higher in both Jordan and Morocco but is still acceptable for international standards, especially compared to developing economies. ${ }^{8}$ However, and while this ratio provides important information on a PEA capacity to do intermediation, it is the job placement rate that is critical for evaluating its efficiency. In Egypt, less than 5 percent of registered job seekers are employed every month, in Jordan less than 3 percent, and in Morocco only about 2 percent.

\subsection{Lack of results-based monitoring and evaluation}

Most publicly provided ALMPs in MENA countries do not have proper monitoring and evaluation (M\&E) frameworks. User feedback is largely absent, as is information

Table 3 Job-Seekers-to-Vacancy Ratio and Number of Job Placements per 1,000 Registered Job Seekers, Selected MENA Countries, 2009

\begin{tabular}{|c|c|c|c|c|c|}
\hline Country & $\begin{array}{l}\text { Number of } \\
\text { registered } \\
\text { job seekers } \\
\text { (thousands) }\end{array}$ & $\begin{array}{l}\text { Number of } \\
\text { registered } \\
\text { job vacancies } \\
\text { (thousands) }\end{array}$ & $\begin{array}{l}\text { Number of job } \\
\text { seekers per } \\
\text { one registered } \\
\text { vacancy }\end{array}$ & $\begin{array}{c}\text { Average } \\
\text { placements } \\
\text { per month } \\
\text { (thousands) }\end{array}$ & $\begin{array}{c}\text { Job placements } \\
\text { per } 1,000 \text { job } \\
\text { seekers per } \\
\text { month }\end{array}$ \\
\hline Egypt, Arab Rep. & 895.1 & 222.9 & 4.0 & 40.1 & 45 \\
\hline Jordan & 28.0 & 2.6 & 10.8 & 0.7 & 25 \\
\hline Lebanon $^{a}$ & 12.2 & 3.6 & 3.4 & - & - \\
\hline Morocco & 517.0 & 27.7 & 18.7 & 4.4 & 9 \\
\hline Tunisia & 105.4 & - & - & 1.6 & - \\
\hline
\end{tabular}

Source: Angel-Urdinola et al. 2013.

Note: $-=$ not available

a. Beirut only. 
about the impacts and cost-effectiveness of programs. Most of the ALMPs surveyed by Angel-Urdinola et al. (2013) have output-based monitoring systems - whereby the monitoring system focuses only on tracking the number of people benefiting from different services. Indeed, monitoring systems in MENA rarely track results-based indicators related to the quality of the service or whether services contributed to improved labor market outcomes of beneficiaries, such as their insertion to the labor market, their wage, of their employment status (e.g. moving from informal to formal employment). Data on program outcomes, such as insertion rates and wages after program completion, were not available for most of the programs included in the study. Moreover, rigorous program evaluations assessing the effectiveness of services provided is largely lacking. Only a small minority (15 percent) conducted an impact evaluation, and a mere handful (7 percent) carried out a cost-effectiveness analysis. Most of the evaluations that were done lacked scientific rigor, rarely using control groups that would have allowed for an estimation of the programs' net impact. For example, Morocco recently evaluated its three main ALMPs, but these evaluations were, for the most part, qualitative and did not assess the program's direct impact on labor market outcomes. In Tunisia, there have been some attempts to evaluate employment programs delivered by the public employment agency, ANETI, but results are outdated, sporadic, donor-driven, and lacking in scientific credibility (Belghazi 2012).

Table 4 shows the main findings of some of the few available rigorous impact evaluations of ALMPs in the MENA region, all of which have been financed and carried out by donors, especially the World Bank. It is important to point out that none of these recent evaluations are of training programs, the most common type of ALMP in MENA countries. In fact, three out of the four available impact evaluations are of

Table 4 Results of Available Impact Evaluations of ALMPs in the MENA region

\begin{tabular}{|c|c|c|c|c|}
\hline Program & Type of Program & Country & $\begin{array}{l}\text { Author of } \\
\text { study }\end{array}$ & Main Findings \\
\hline \multirow[t]{2}{*}{$\begin{array}{l}\text { New Work } \\
\text { Opportunities for } \\
\text { Women (NOW) }\end{array}$} & $\begin{array}{l}\text { Wage Subsidy + life skills } \\
\text { training }\end{array}$ & Jordan & $\begin{array}{l}\text { Groh et al. } \\
(2012)\end{array}$ & $\begin{array}{l}\text { Wage subsidy: Large positive } \\
\text { effect on employment in the } \\
\text { short term; No impact after } \\
14 \text { months. }\end{array}$ \\
\hline & & & & $\begin{array}{l}\text { Life skills: no effect on } \\
\text { employment in the short term. } \\
\text { Little positive impact on } \\
\text { employment in the } 14 \text { months } \\
\text { after program completion. } \\
\text { Positive changes in behavioral } \\
\text { skills. }\end{array}$ \\
\hline $\begin{array}{l}\text { Business thesis } \\
\text { plan competition }\end{array}$ & $\begin{array}{l}\text { Entrepreneurship: awareness + } \\
\text { technical and life skills } \\
\text { training + coaching. }\end{array}$ & Tunisia & $\begin{array}{l}\text { Premand et al. } \\
(2011)\end{array}$ & $\begin{array}{l}\text { No effect on net employment. } \\
\text { Changed the composition of } \\
\text { employment (from wage to } \\
\text { self-employment). Positive } \\
\text { changes in behavioral skills }\end{array}$ \\
\hline Al Amana & $\begin{array}{l}\text { Entrepreneurship: access to } \\
\text { micro-credit }\end{array}$ & Morocco & $\begin{array}{l}\text { Cho and } \\
\text { Honorati (2012) }\end{array}$ & $\begin{array}{l}\text { Increased household self- } \\
\text { employment. Little or no effect } \\
\text { on average consumption or } \\
\text { other outcomes (health, } \\
\text { education, etc.). }\end{array}$ \\
\hline Shabab & $\begin{array}{l}\text { Entrepreneurship: awareness } \\
\text { (other program components - } \\
\text { e.g. technical skills - have yet to } \\
\text { be evaluated) }\end{array}$ & Syria & Haddad (2010). & $\begin{array}{l}\text { Increased knowledge of and } \\
\text { changed attitude (positively) } \\
\text { toward self-employment. }\end{array}$ \\
\hline
\end{tabular}


entrepreneurship programs, highlighting an increasing interest by the donor community to assess the impact of this type of programs in the region. This could be partly explained by the fact that entrepreneurship is seen by many as a possible response to some of the main labor market challenges in the MENA region, especially in light of poor economic growth and low investment levels. The findings of these evaluations will be used in the next section as evidence supporting the reform agenda for ALMPs in the MENA region proposed in this study.

\subsection{Program design}

The success of ALMPs depends largely on program design and implementation. To effectively address a given failure in the labor market, it is critical to choose the right type of ALMP. Equally important is identifying the specific design features that will increase the likelihood of program success, independently of the program type. This section describes the main design challenges found among the publicly provided ALMPs in MENA countries that were surveyed by Angel-Urdinola et al. (2013).

Poor targeting practices Programs in the study do not use a consistent targeting methodology. While some define a target group and eligibility criteria, weak institutional capacity, limited access to data, and lack of information lead to poor targeting practices. For instance, while some ALMPs target first-time job seekers, few programs identify who among their beneficiaries will be hard to place. Therefore, these programs end up benefiting individuals who would have obtained jobs without any intervention, leading to deadweight losses. For instance, following the Jasmine Revolution, Tunisia introduced a program called AMAL ("hope" in Arabic), which provides first-time job seekers with at least an associate's degree from an accredited institution a monthly stipend conditional on their participation in training, counseling, and/or internships. Given Tunisia's demographics and highly educated workforce, the pool of potential beneficiaries far exceeded the Government's capacity to deliver AMAL's services to the 145,000 (versus the expected 50,000) jobseekers who enrolled in the program in 2011. In fact, out of those who enrolled, less than 20 thousand received any type of service. As a result, AMAL became, for the most part, a cash transfer program with negative repercussions on the nation's budget and on the employment outcomes of beneficiaries, as the stipend allowed many to remain idle and continue to wait for public sector jobs (Belghazi 2012).

Supply-driven and in-class training programs The majority of training programs in the study are supply-driven, and only a few are designed in close collaboration with the private sector. Most are conducted in classrooms and focus largely on the provision of hard skills. Only a few programs in the study focus on the provision of soft skills and/ or practical experience through on-the-job training. ${ }^{9}$ Both hard and soft skills, as well as practical experience, are essential to increase the employability and insertion of program beneficiaries. A recent evaluation of youth employment programs showed that comprehensive programs-those combining in-class training with practical experience, or combining in-class training and practical experience with other services such as life skills training and counseling-have higher rates of success, with success defined as 
improving the probability of obtaining employment and/or higher earnings. In contrast, programs offering only in-class training or only practical experience were less successful. Indeed, international evidence suggests that traditional in-class training programs have a negative impact on beneficiaries' chances of employment. However, the success of training programs increases when they include life-skills or on-the-job training or both (World Bank 2012).

Entrepreneurship programs are limited in scope Entrepreneurship programs have traditionally been at the core of employment policy in many MENA countries. Most of these programs target the low-skilled unemployed and are delivered by social funds (Egypt and Yemen), microcredit institutions (Tunisia), or donors (Egypt, Lebanon) (Angel-Urdinola et al. 2010). National employment agencies in Egypt, Lebanon, Morocco, Tunisia, and Syria are now offering training programs for those registered unemployed who want to establish their own business (Angel-Urdinola et al. 2013). However, entrepreneurship programs in MENA countries typically benefit relatively few people and do not address some of the other key constraints facing potential entrepreneurs, such as access to credit and the need for personalized coaching and incubator services.

Lack of graduation/exit strategies Many employment programs in MENA countries lack a clear graduation/exit strategy, allowing program beneficiaries to become dependent on government support and to stay in programs indefinitely. Benefits are often too high and continue for too long, which creates distortions in the labor market and discourages the unemployed from actively searching for a job. Transfers at such levels are also fiscally unsustainable. While some programs provide referrals to employment services and require beneficiaries to comply with certain conditions to continue receiving benefits, these conditions for the most part are not enforceable, given the lack of monitoring systems and other capacity constraints. For example, in Tunisia, research from Belghazi (2012) indicates that ALMP beneficiaries can benefit from programs consecutively for long periods of time, often longer than 5 years.

Lack of signaling Although its performance is far from ideal, the public sector is doing better than the private sector in terms of program certification. In the MENA region, as in most regions of the world, a diploma signals that its bearer has achieved a particular level of knowledge and competence, allowing access to higher levels of instruction. Angel-Urdinola et al. (2010) find that less than 10 percent of training programs delivered by private providers in MENA countries provide beneficiaries with some type of recognized credential upon program completion. In comparison, about 50 percent of publicly provided training programs in the region do so. However, certification practices vary from country to country. For example, Yemen and Syria largely lack standard certification systems and national qualifications frameworks, while Lebanon and Jordan have accreditation systems that are better developed (Angel-Urdinola et al. 2013).

Lack of coordination with the private sector ALMPs in the MENA region are, for the most part, conceived at the national level without taking into account regional and 
local realities. Other important stakeholders, notably the private sector, are not consulted at the design stage, which makes ALMPs ineffective in addressing the needs of the labor market. In the case of ALMPs that seek to encourage labor demand through wage subsidies, lack of ownership discourages companies from implementing program components and from investing in program beneficiaries. This translates into high levels of turnover among program beneficiaries and overall low insertion levels. In Tunisia, administrative data indicate that less than 15 percent of all beneficiaries who benefit from ALMPs find employment after program completion. Also, public employment agencies rarely accredit or assess the performance of the private operators they work with to deliver ALMPs. Most private contractors are paid based on outputs, usually the number of people trained, rather than based on the quality of the service delivered. Consequently, many training programs offered by private providers are supply-driven and of poor quality (Angel-Urdinola et al. 2013).

\section{A policy framework for the MENA region}

This section proposes a policy framework for improving the delivery of publicly provided ALMPs in the MENA region. The 4 main obstacles to the effective and efficient delivery of publicly provided ALMPs in the MENA region as discussed in Section IV above are presented in column 1 of Table 5 below. Column 2 includes some concrete examples of each of the 4 challenges, and Column 3 identifies four main policy directives to address these constraints: (i) develop results-based public-private partnerships (PPPs); (ii) develop results-based monitoring and evaluation (M\&E) frameworks; (iii) promote new approaches to entrepreneurship, on-the-job training (OJT), and life skills training among job seekers; and (iv) promote systems and program integration. Policy directives can apply to many or all concrete examples of one or more of the 4 constraints. For example, the policy directive "promote systems and program integration" applies to all the concrete examples of the "system and program fragmentation" constraint, but it also applies to one of the concrete examples (Poor data quality of registries) of the "limited administrative capacity" constraint.

The policy directives included in the framework are based on available information of what works and does not work in MENA countries, as well as on documented experiences and lessons learned from throughout the world (Additional file 1: Table A1). The main policy instruments that could be used to advance this policy agenda are described below and summarized in Table 6 .

\subsection{Develop results-based public-private partnerships}

The importance of including the private sector in the delivery of employment services was confirmed by the Private Employment Agencies Convention adopted by the International Labour Organization (ILO) in 1997 (Convention 181 supported by Recommendation 188). It encouraged "cooperation between the public employment service and private employment agencies in relation to the implementation of a national policy on organizing the labour market." For PES, one of the main advantages of cooperating with or subcontracting other actors is that they offer more specialized services, which are needed in light of the increasing complexity of the labor market. Nevertheless, some countries in the region (e.g. Tunisia, Yemen, Iraq, Kuwait, Saudi Arabia, Oman, 


\begin{tabular}{|c|c|c|}
\hline Constraint & & Policy directive \\
\hline \multirow{6}{*}{$\begin{array}{l}\text { Limited administrative } \\
\text { capacity }\end{array}$} & $\begin{array}{l}\text { Insufficient ratio of counselors to registered } \\
\text { unemployed }\end{array}$ & \multirow{5}{*}{ Develop results-based PPPs } \\
\hline & Insufficient national coverage & \\
\hline & Inadequate skills of counselors & \\
\hline & Lack of performance incentives & \\
\hline & Weak intermediation capacity (prospection) & \\
\hline & $\begin{array}{l}\text { Poor data quality of registries (nomenclature, } \\
\text { qualifications) }\end{array}$ & \multirow{5}{*}{$\begin{array}{l}\text { Promote systems and } \\
\text { program integration }\end{array}$} \\
\hline \multirow{4}{*}{$\begin{array}{l}\text { System and Program } \\
\text { fragmentation }\end{array}$} & Too many public players in the provision of ALMPS & \\
\hline & $\begin{array}{l}\text { Lack of integration of ALMPs with safety net } \\
\text { systems }\end{array}$ & \\
\hline & Lack of inter-institutional coordination & \\
\hline & $\begin{array}{l}\text { Program fragmentation (too many small programs } \\
\text { and lack of coherence across programs) }\end{array}$ & \\
\hline \multirow{4}{*}{ Lack of results based M\&E } & Lack of results-based M\&E systems and frameworks & \multirow{6}{*}{$\begin{array}{l}\text { Develop results-based M\&E } \\
\text { frameworks }\end{array}$} \\
\hline & Lack of systems to promote user feedback & \\
\hline & Lack of accreditation of private providers & \\
\hline & $\begin{array}{l}\text { Lack of information about quality of private } \\
\text { providers }\end{array}$ & \\
\hline \multirow{6}{*}{ Flawed program design } & Poor insertion rates & \\
\hline & Poor targeting & \\
\hline & Lack of graduation/exit strategies & $\begin{array}{l}\text { Promote systems and } \\
\text { program integration }\end{array}$ \\
\hline & $\begin{array}{l}\text { Lack of involvement by the private sector in } \\
\text { program design }\end{array}$ & \multirow{3}{*}{$\begin{array}{l}\text { Promote entrepreneurship/ } \\
\text { self-employment, on-the-job- } \\
\text { training, and life skills } \\
\text { training among job seekers }\end{array}$} \\
\hline & $\begin{array}{l}\text { Failure to focus on provision of soft skills and/or } \\
\text { on-the-job-training }\end{array}$ & \\
\hline & $\begin{array}{l}\text { Entrepreneurship programs that are limited in } \\
\text { focus and scope }\end{array}$ & \\
\hline
\end{tabular}

Source: Authors own elaboration. See Additional file 1: Table A1.

and United Arab Emirates) have not ratified this convention and their public employment agencies continues to have the monopoly in the provision of employment services - although in most of these countries, private employment agencies operate in one way or another. Therefore, easing any regulation constraints inhibiting the participation of the private sector in the provision of employment services should be a priority for these countries, especially in light of the limited capacity of their public employment agencies to provide services to an increasing number of job seekers.

Public-private partnerships can improve the delivery of ALMPs if incentives are designed to provide high-quality services and if the performance of private partners is monitored and evaluated against specific, predetermined results. In most high-income countries, public employment agencies do not have a monopoly on the delivery of employment services. In fact, in the Netherlands all job seekers are referred to external service providers, with public authorities serving primarily as gatekeepers of a private quasi-market. However, Dutch public authorities are generally still responsible for processing payments. Private providers can be employment agencies, including temporary employment, recruitment, and guidance/counseling agencies; they may also be training 
Table 6 Main Policy Instruments for Improving service delivery

\begin{tabular}{|c|c|c|c|}
\hline $\begin{array}{l}\text { Develop results-based } \\
\text { Public Private } \\
\text { Partnerships }\end{array}$ & $\begin{array}{l}\text { Develop results-based } \\
\text { M\&E frameworks }\end{array}$ & $\begin{array}{l}\text { Promote high-end } \\
\text { entrepreneurship, OJT, } \\
\text { and life skills training } \\
\text { among job seekers }\end{array}$ & $\begin{array}{l}\text { Promote systems and } \\
\text { program integration }\end{array}$ \\
\hline $\begin{array}{l}\text { - Subcontract with private } \\
\text { providers using } \\
\text { performance-based } \\
\text { contracts (based on } \\
\text { placement rates) for } \\
\text { provision of training and } \\
\text { intermediation services }\end{array}$ & $\begin{array}{l}\text { - Adopt proper results- } \\
\text { based M\&E systems and } \\
\text { ensure proper financing } \\
\text { for periodic program } \\
\text { evaluation. }\end{array}$ & $\begin{array}{l}\text { - Develop training on } \\
\text { entrepreneurship } \\
\text { awareness. }\end{array}$ & $\begin{array}{l}\text { - Promote one-stop shops } \\
\text { for ALMPs, unified } \\
\text { registry, program } \\
\text { consolidation. }\end{array}$ \\
\hline $\begin{array}{l}\text { - Use information and } \\
\text { communication } \\
\text { technologies to foster } \\
\text { intermediation }\end{array}$ & $\begin{array}{l}\text { - Pilot and evaluate } \\
\text { programs before scaling } \\
\text { up nationally. }\end{array}$ & $\begin{array}{l}\text { - Facilitate access to } \\
\text { finance }\end{array}$ & $\begin{array}{l}\text { - Use ALMPs as } \\
\text { graduation/exit } \\
\text { strategies for existing } \\
\text { safety net programs. }\end{array}$ \\
\hline $\begin{array}{l}\text { - Develop training } \\
\text { programs in close } \\
\text { coordination with the } \\
\text { private sector (focus on } \\
\text { soft skills) }\end{array}$ & $\begin{array}{l}\text { - Conduct periodic social } \\
\text { audits and user } \\
\text { satisfaction surveys. }\end{array}$ & $\begin{array}{l}\text { - Develop programs to } \\
\text { enhance the productivity } \\
\text { of potential self- } \\
\text { employed workers (e- } \\
\text { lancing, provision of } \\
\text { market information, etc.) }\end{array}$ & $\begin{array}{l}\text { - Establish inter-ministerial } \\
\text { committees/task forces } \\
\text { on employment } \\
\text { programs (centrally and } \\
\text { regionally) and involve } \\
\text { the private sector }\end{array}$ \\
\hline \multicolumn{4}{|l|}{$\begin{array}{l}\text { - Liberalize and ease } \\
\text { regulation bottlenecks for } \\
\text { the provision of private } \\
\text { intermediation services } \\
\text { (e.g., in Tunisia) }\end{array}$} \\
\hline $\begin{array}{l}\text { - Develop national } \\
\text { qualification frameworks } \\
\text { and proper and periodic } \\
\text { accreditation systems for } \\
\text { providers }\end{array}$ & & $\begin{array}{l}\text { - Broaden the focus of } \\
\text { existing training } \\
\text { programs to include } \\
\text { both OJT and life skills } \\
\text { training }\end{array}$ & \\
\hline
\end{tabular}

Source: Authors own elaboration.

and educational institutions, community-based organizations, and employers themselves. Partnering with private service providers can ensure that programs respond to market conditions, thus improving labor market outcomes among program beneficiaries.

Contracting out is key to ensuring more effective and efficient PPPs. Service contracts with private providers are typically performance-based, covering a provider's base costs while providing an incentive for placement through a bonus tied to outcomes. ${ }^{10}$

Results-based contracting has become an international best practice. According to a recent OECD report, Job Services Australia, the country's system for delivering employment services, may have contributed to the strong performance of the Australian labor market which, since 2009, has had the highest employment rate among G7 and OECD G20 countries. Job Services Australia is the pioneer of results-based contracting for the delivery of employment services. It features a one-stop shop that refers all the registered unemployed to for-profit and non-profit providers, which participate in a competitive call for proposals and are awarded contracts that pay a standard service fee plus a bonus both for results and for serving the hardest-to-place job seekers (Tergeist and Grubb 2006) (Additional file 1: Table A1).

Based on the Australian model, other countries have also successfully introduced performance-based systems to deliver employment services. For example, UK's Jobcentre Plus provides payments to contractors depending on: (i) job outcome (off-flow from benefit into employment) and (ii) sustainability of jobs (retention after 13/ 26 weeks). This is also the case in Germany, where a placement voucher entitles the 
job seeker to use a private agency. If the voucher leads to employment, the agency receives a predetermined percentage of the payment at insertion and the remainder six months after placement (Schneider 2008). Nordic countries, which have a strong tradition of delivering employment services solely through their public employment agencies, are also in the middle of reforming their systems to include private providers in the delivery of public employment services. Results-based contracting requires a welldeveloped network of private employment providers that may be lacking in most MENA countries. However, developing the capacity of private employment providers (and NGOs) as well as putting in place systems and procedures to help Governments in MENA countries manage this kind of system seems a plausible option to improve the delivery of public employment services in the short-run, especially given the region's political economy and the weak administrative capacity of its public employment agencies. Of course, in the long-run, a comprehensive public sector reform will be required.

Beyond PPPs and results-based contracting, developing and implementing training programs in close collaboration with the private sector is also highly recommended. The Siyaha Project in Jordan is an example of an ALMP that successfully involved the private sector throughout the project cycle. Siyaha is a demand-driven training program financed by USAID that seeks to enhance the quality of training offered by the Vocational Training Centers of the Ministry of Tourism in Jordan. Specifically, Siyaha finances: (i) the upgrading of the Vocational Training Centers, (ii) the revision of the Centers' curriculum, in close collaboration with the tourism industry specialists, (iii) the introduction of soft-skills modules, and (iv) mandatory on-the-job training, whereby the Vocational Training Centers sign contracts with accredited hotels and restaurants to promote quality control and assurance. Siyaha targets primarily low-income youth and women, all of whom receive an internationally accredited certification upon completion of the program. From 2006 to 2010, Siyaha benefited 3,000 individuals of whom 1,100 graduated from the program. From those who graduated, 57 percent landed a job (USAID, Jordan Tourism Development Project - Siyaha. 2006-2007 Annual Report).

As public agencies in the region begin to work in partnership with the private sector, it will be necessary to develop instruments that assist relevant stakeholders to promote quality assurance and recognition of training programs delivered by the public and private sector. For example, the development of a Qualifications Framework (QF), defined as "an instrument for the development, classification and recognition of skills, knowledge and competencies along a continuum of agreed levels" (Tuck 2007); can serve as the basis for improving the quality and relevance of education, thus addressing the skills mismatches that are so prevalent in MENA countries. At the regional level, QFs can improve comparability of qualifications, promote mutual recognition of qualifications, encourage credit transfer, develop national standards, and facilitate agreement on entrance requirements for higher education (Tuck 2007).

Finally, in order to improve the effectiveness of labor intermediation services, it is recommended that public employment agencies partner with the private sector to use information and telecommunication technologies (ICTs) to better disseminate market information. Souktel provides a concrete example of how the use of technology can improve labor intermediation services in the MENA region. Souktel is a private enterprise (established in 2006) that promotes the use of mobile phone to link people with jobs, 
thus reducing information asymmetries and frictional unemployment in selected communities. In the Palestinian Territories, Souktel serves 10,000 job-seekers and 200 employers daily. A recent qualitative evaluation of this initiative shows that $84 \%$ of those job seekers surveyed in the Palestinian Territories experienced a reduction in jobsearch time from 12 weeks to less than 1 week, and 64\% report higher monthly incomes as a result of jobs sourced through the service. In addition, over $50 \%$ of the surveyed job-seekers report that they are now able to support 3 or more additional family members through new income resulting from job matches. On the other hand, $70 \%$ of surveyed Palestine employers who use Souktel's services reported a 50\% or greater reduction in hiring costs and time, and $75 \%$ of the same sample confirmed a mean 5\% increase in annual revenue, after hiring staff through Souktel (Souktel 2013. Analysis and results produced specifically for this paper).

\subsection{Develop results-based Monitoring \& Evaluation (M\&E) frameworks}

Developing results-based $M \& E$ frameworks will be critical to improve the governance, effectiveness and efficiency of ALMPs in MENA countries, especially in light of the increased demands for greater governance and social accountability post Arab Spring. MENA countries need to establish a clear governance structure, quality assurance mechanisms, and an M\&E strategy based on results, not merely outputs, to increase program efficiency and effectiveness and improve the use of public resources. Rigorous, independent impact evaluations are needed to demonstrate what works, to enhance capacity in the region, and to improve overall policy making. Also, it is crucial to conduct impact evaluations of new pilot programs before scaling-up nationally, in order to make the necessary adjustments to program design and thus avoid scaling-up interventions that are not effective or efficient.

Australia and Sweden are perhaps the best examples of how countries can effectively mainstream M\&E practices into the policy-making process. Their M\&E systems require that every program be evaluated every three to five years. Each ministry has to prepare an M\&E plan to evaluate their programs, identifying required resources as well as potential policy implications. In addition, all completed M\&E activities must be recorded and published for transparency purposes. In all, well established M\&E systems improve service delivery, strengthen program governance and accountability, and promote a culture of evidence-based policy making (Mackay 2011; Laguna 2011; and Lahey 2011). While resources and capacity in many developing countries are not aligned to those in countries like Australia and Sweden, more and more employment programs, even in the developing world, have started to include monitoring systems and to be evaluated. In developing countries, however, these evaluations are generally donor driven. In order to develop and improve this culture of M\&E it is recommended that (i) monitoring focuses on outcomes and not on outputs, (ii) program evaluation financing is part of the program's budget and/or proper budget allocations are made for monitoring and evaluation. While impact evaluations could be regarded as costly and methodologically challenging (often requiring the identification of control groups that are deprived from a certain service at some point of time), the cost of impact evaluation are often small when compared to total program allocations. It is also recommended that private and independent firms conduct these impact evaluations, but in close consultation with main stakeholders to assure their validity and acceptance. 
Concerning monitoring, setting up performance targets is a common way to improve service delivery of employment programs and services. Key quantitative indicators may include the number of visitors to local employment offices, registered job seekers, participants in ALMPs, placements, and job vacancies filled within a certain time. Performance targets might include an increase in the public employment agency's market share of vacancies reported by firms and a reduction in the prevalence of unemployment that is long-term (over one year) or very long-term (two years or more). A key qualitative indicator is satisfaction on the part of job seekers and employers with the public employment agency's services. A results-based monitoring system enables the oversight entities to intervene early when needed with corrective or countering action. It is also useful to develop periodic social audits and systems/surveys to collect information about user satisfaction and complains.

At a minimum, every public employment agency should periodically collect data on the following core indicators (Betcherman et al. 2010):

- Job placement rate. The number of registered unemployed in quarter $t$ who are employed in quarter $t+1$.

- Placement cost. Number of beneficiaries who obtained a job in year $t$ divided by program budget in year $t$.

- Job retention rate. The number of registered unemployed in quarter $t$ who are employed in both quarters $t+2$ and $t+3$.

- Average earnings. Average earnings in quarters $t+2$ and $t+3$ for those registered unemployed in quarter $t$ who retained employment in these quarters.

- Filled vacancy rate. The number of registered job vacancies in quarter $t$ that are filled by registered job seekers in quarter $t+1$.

- Adequacy Rate: The share of individuals who complete training in quarter $t$ who are employed in quarter $t+1$ in an occupation compatible with the training provided.

- Underemployment Rate: The share of individuals who complete training in quarter $t$ who are employed in quarter $t+1$ in a work that requires a lower education profile.

\subsection{Promote entrepreneurship and self-employment}

Much of the private sector in the MENA region is made up of small firms that lack incentives to diversify, innovate, and invest, which undermines their ability to grow and create quality employment. Obstacles include burdensome business regulations and discretionary enforcement, low skill levels among entrepreneurs, poor access to credit, and subsidies that distort energy prices (Gatti et al. 2012). Given the increasing number of university graduates and the limited absorption capacity of the public sector, it is no surprise that many MENA countries face deteriorating labor market outcomes. For this reason, promoting a culture of entrepreneurship that encourages experimentation and learning among youth, especially unemployed university graduates, can improve labor market outcomes.

Most MENA countries have developed entrepreneurship programs, and these have had, for the most part, a limited impact on youth employment. These efforts are limited in scale and scope, targeting primarily the low-skilled, whose businesses tend to remain small and thus have a limited impact on job creation (See Premand et al. 2011; 
Cho and Honorati 2012; and Haddad 2010 in Table 4). Several studies show that educational levels among the owners of micro and small informal enterprises are an important determinant of innovation, rate of return on capital, and employment growth (World Bank 2012).

While there is little evidence showing that entrepreneurship programs have an effect on labor market outcomes, a recent meta regression analysis (See Cho and Honorati, World Bank 2012 in Table 4 and Additional file 1: Table A1) shows that entrepreneurship programs have a positive effect on beneficiaries' attitude towards self-employment, an important result considering a strong preference for public sector employment among job seekers in the region. For example, evidence from the Business Thesis Plan Competition in Tunisia, which allows university students to develop a business plan rather than a traditional thesis to meet graduation requirements, shows that the provision of entrepreneurship training and personalized coaching is effective in increasing the rate of self-employment among university graduates. Of course, these types of initiatives need to be complemented with information, coaching, access to credit, as well as with other instruments such as incubators and guarantee funds.

Given that labor markets in some MENA countries are rather informal and that productivity of informal workers and firms in the region is quite low (Gatti et al. 2012), programs seeking to increase the productivity of informal self-employed workers and free lancers have great potential in the region. Many informal self-employed workers in some MENA countries make below a living wage and are thus unable to support themselves or their families. In addition, they lack the necessary skills to compete in the new global economy. The Samasource initiative provides an example of how employment programs can connect informal workers in disadvantaged markets to the global digital economy. Samasource is a non-profit organization that owns a technology platform (the SamaHub) that breaks down digital work from large companies (such as Google or Intel) into small tasks, or microwork, that can be completed by workers (notably youth and women) with basic English skills and a few weeks of training at the company's partner centers. Samasource works with in-country NGO partners to recruit women and youth formerly earning below a local living wage, as determined by the Fair Wage Guide. These recruits receive 2-4 weeks of computer-based training on the SamaHub, including English and soft skills. Workers stay in the program for an average of 8-12 months, after which they move on to more advanced employment within their ICT center, another employer, or return to school. To date, Samasource has connected over 3,000 people to $\$ 2.5$ million in living wages across 9 countries, notably India and Kenya. About $75 \%$ of their beneficiaries transition out of Samasource work after one year and $88 \%$ report to have been able to find a better job based on the experience they gained in the program (World Bank 2012a).

The Babajobs initiative is another interesting example of how increased access to information can improve self-employment opportunities, by providing labor intermediation services to informal workers. Babajob.com is a web and mobile start-up dedicated to bringing better job opportunities to the workers in the informal sector (cooks, maids, security guards, office helpers, etc.) in India by connecting employers with job seekers via the web, mobile apps, SMS, the mobile web and voice services. Since its creation in 2007, Babajob has advertised over a million job postings, benefiting over 70,000 registered employers, including many of the largest low-end employers such as Coffee Day, 
Yum Brands (Pizza Hut, KFC), and Dustbusters (25,000 housekeeping staff). Babajobs users report an average earnings increase of $20.1 \%$ and a reduction in their average commute time by 14 minutes per day (World Bank 2012a).

\subsection{Promote on-the-job and life skills training}

As mentioned before, training programs are widely used by countries throughout the MENA region, but most are provided in-class and are supply-driven. However, international evidence indicates that the effectiveness of training programs (as measured by their insertion rates) increases when they include life-skills, on-the-job training or both (World Bank 2012). While some of the recent available rigorous impact evaluations of ALMPs in MENA countries (Table 4) show that their life skills component had little or no impact on labor market outcomes, all three evaluations showed the importance of life skills for students' behavioral development. On the other hand, existing literature reveals that on-the-job training programs have large positive effects on employment outcomes, especially when they are well-targeted (Additional file 1: Table A1). Thus, and given that lack of work experience is a major constraint to job insertion in the region (e.g.: fifty percent of the total unemployed in Morocco are first-time job seekers), increasing on-the-job training opportunities for unemployed youth in the MENA region is critical to improve labor market outcomes in the region. A recent evaluation by the Inter-American Development Bank of the Juventud y Empleo program in the Dominican Republic found that in the short run, the life skills package (on-the-job training + life skills) was more cost-effective than the traditional vocational training package (on-the-job training + vocational training + life skills) (Martinez 2013) (Additional file 1: Table A1).

Beyond training programs, secondary schools in MENA countries do not teach life skills, partly because they are not measured by achievement tests. The few people who have access to life skills training in the region are those who benefit from life skills modules developed and implemented by civil society organizations. As a result, and as highlighted in the World Bank MENA report on Jobs (World Bank 2012), about onethird of employers interviewed in Egypt, Jordan, and Yemen complained about the lack of life skills of their recently hired employees.

\subsection{Promote Systems and Program Integration}

As discussed before, many MENA countries have developed a plethora of small and independent employment and social programs that target various groups and that are implemented at different geographic levels and by different stakeholders. In many cases, these programs lack complementarity and coherence, thus leading to redundancy and inefficiencies. It is therefore critical to promote systems and program integration, as this will help countries improve the effectiveness, efficiency, and governance of their social protection and labor (SP\&L) programs. For example, between 2009 and 2012, Tunisia consolidated 41 employment programs into four main ALMPs (training, wage subsidies, public works, and entrepreneurship support) and the country is currently in the process of introducing biometric cards to better identify, target, and monitor program beneficiaries. It is hoped that this reform paves the way for the development of a SP\&L system that includes social assistance and other relevant programs, thus helping Tunisia improve coordination and service delivery at all levels. 
Building SP\&L systems is critical to improve coordination and integration at the administrative, program and policy level. At the administrative level, promoting the development of SP\&L systems requires the development of management, information and service delivery tools. This may include: beneficiary identification systems and registries, targeting schemes, M\&E, etc. At the program level, SP\&L systems effectively promote the integration within and across employment and social programs, by focusing on design and implementation issues ranging from targeting to M\&E. At the policy level, SP\&L systems "ensure policy coherence attuning the entire portfolio of SP\&L programs to act coherently in delivering national goals and social contracts" (Robalino et al. 2012).

SP\&L systems require collaboration and sustained, coordinated efforts by all stakeholders. It is a gradual process that depends on strong government support and close partnerships with the private sector. A possible way to start this process is by designing and piloting programs that introduce specific design and administrative features that help integrate employment and social programs. These features include beneficiary registries, cash delivery mechanisms, and unified targeting approaches. These pilots can then be evaluated and, if successful, replicated at the national level, where they can serve as the basis for SP\&L systems that are cost-effective and embedded into the country's broader policy environment (Figure 2).

To ensure the sustainability of SP\&L systems, it is critical to engage in capacitybuilding activities targeted to key stakeholders, to promote ownership, and to involve nontraditional partners (especially the private sector) in the design and implementation of employment and social programs. Sharing of information and data access must be expanded and strengthened. A number of countries have successfully established effective SP\&L systems. For example, the United Kingdom established a one-stop shop known as Jobcentre Plus, where beneficiaries of employment and social programs can access a variety of services in a single place. Having a one-stop shop reduces transaction and administrative costs, improves service delivery, and facilitates program monitoring and evaluation.

The development of SP\&L systems is intrinsically linked to the promotion of the activation agenda, whereby beneficiaries from social assistance exit into ALMPs and eventually into jobs. The activation agenda is of utter importance for the MENA region, as subsidies (untargeted and pro-rich) represent the most important safety net for disadvantaged populations in the region. As countries in the MENA region reform subsidies and introduce targeted safety net programs, improved coordination among Ministries, especially Labor and Social Affairs, will be critical to promote systems and program integration.

Finally, accreditation and licensing of providers as well as the employment services they provide (notably in the areas of training and intermediation) is also key to ensure quality assurance and control of the services rendered. For example, in Germany, service providers must apply for their accreditation and for the licensing of their courses through a national accredited private body. Specifically, they have to prove that they have the adequate financial and human capacity to: (i) provide quality and relevant training through experienced teachers, (ii) support the integration of their trainees into employment; and (iii) effectively monitor student progress to ensure quality assurance and development. In addition, in order for their courses to be eligible for licensing and 
for public resources, training providers must define the target population's prospects for insertion in the labor market as well as the content and time frame for the training course, including adequate practical working experience. Accreditation and licensing of providers and their courses is critical to improving the chances of employment of beneficiaries, as it "leads to a publicly visible (quality) label" (European Union 2009).

\section{Conclusion}

The MENA region is facing a number of serious challenges affecting its labor markets. They include sluggish labor demand, high rates of joblessness among youth and women, prevalence of skills mismatches, stagnant labor mobility, high rates of informal employment, and lack of formal employment networks. Active labor market programs could play an important role in addressing market failures related to labor demand, labor supply, and information asymmetries, thus increasing the employability and employment chances of program beneficiaries. However, the efficiency and effectiveness of ALMPs depends largely on their design, as well as on the country's institutional capacity to implement them.

ALMPs have been widely used in the MENA region. While some MENA countries, namely Tunisia and to some extent Morocco, still provide ALMPs primarily through the public sector, others, such as Lebanon, Egypt, and Jordan, actively involve the private sector in the provision of training, job brokerage, and other labor market services. However, as noted in this study, public and private provision of ALMPs in MENA countries face important institutional and operational challenges that hinder their efficiency and effectiveness. These include limited administrative capacity, system and program fragmentation, lack of adequate monitoring and evaluation systems, and flaws in program design.

Leveraging available literature and some of the few robust impact evaluations of ALMPs in MENA countries, this study proposes a series of reforms to improve the performance of ALMPs in the MENA region. In particular, the study reveals an urgent need to involve the private sector in the design and implementation of employment programs in the region.. Many programs are currently designed and delivered solely by public agencies and do not necessarily provide job seekers with the tools and skills they need to access available vacancies. Partnering with the private sector for the delivery of ALMPs will, therefore, be pivotal as a means to develop employment programs that better prepare beneficiaries to respond to the needs of the private sector. These partnerships should include strong governance mechanisms to ensure they deliver concrete results. Providers of employment programs should, for example, be assessed (and remunerated) based on their demonstrated capacity to connect beneficiaries to available internships and jobs.

Beyond establishing stronger relationships between public and private employment and training agencies, this study proposes a policy framework to improve the delivery of publicly provided ALMPs in the MENA region. It identifies four main policy directives, each of which addresses the main challenges to the effective and efficient delivery of employment services in MENA countries. These policy directives are (a) develop results-based public-private partnerships; (b) develop results-based M\&E frameworks; (c) promote entrepreneurship/self-employment, OJT, and life skills training among job seekers; and (d) promote systems and program integration. 
The effective application of the proposed reform agenda, however, requires that countries in the MENA region satisfy a minimum set of conditions. To begin with, political will is needed at all levels to facilitate the involvement of private entities in the delivery of publicly provided ALMPs. This means enabling private actors to engage in intermediation, as well as reforming national procurement rules and regulations to facilitate contracting and contract management. In addition, institutional capacity building is needed to ensure proper identification, selection, and monitoring of private providers of employment services as well as to engage in effective M\&E of publicly provided ALMPs. The establishment of social protection and labor systems includes setting up administrative systems or improving existing ones, which in turn requires access to quality data as well as improved coordination and information sharing among stakeholders. Finally, in addition to providing technical support to potential entrepreneurs, countries need to promote their financial literacy and access to financing. Less emphasis on public sector hiring can also help promote entrepreneurship among job seekers.

Given these conditions, successfully implementing the proposed policy directives will require galvanizing support and buy-in from various stakeholders, including unions. However, for many MENA countries, there is currently a window for changing the status quo. Efforts to improve employment outcomes among the unemployed should be at the forefront of the policy agenda.

\section{Endnotes}

${ }^{1}$ There are many factors that explain why labor force participation of women in MENA is low for international standards. Some claim that economic reasons explain low female employment rates as market wages offered to unskilled women are below their reservation wage corresponding to the value of their household chores and caretaking (World Bank 2013). Other studies claim that social factors (such as preferences for home-care, marital obligations, and religion) are a fundamental determinant of female employment in the region. The share of women claiming that they are inactive due to family reasons ranges from 85 percent in urban Morocco to 96 percent in Egypt (World Bank 2013). Results from the World Values Survey suggest that women in the MENA region are more likely than women in other parts of the world to view the role of fulltime domestic work as favorably as that of working for pay. Finally, available literature also claims that some laws and regulations discourage or prevent women from having access to the labor market (World Bank 2013).

${ }^{2}$ Employability refers to a person's ability to access a job. This concept is one element in the European Employment Strategy first adopted by the European Union member states in 1997.

${ }^{3}$ The main target groups for activation programs are recipients (or claimants) of income replacement benefits that are conditional on availability for work. This includes most recipients of unemployment benefits. Unfortunately, only a few countries in the MENA region have unemployment insurance systems, namely Algeria, Bahrain, Egypt, the Islamic Republic of Iran, and Kuwait.

${ }^{4}$ In the absence of public regulation, private placement agencies will tend to concentrate on (or "cream off") those unemployed persons who are most easily placed.

${ }^{5}$ Results from the World Bank (2013) indicate that while high-skilled unemployed individuals in countries like Tunisia, Jordan, and Egypt (proxied by those who attained a 
tertiary education degree) account of account for 17 of the labor force, they also account for 20 to 30 percent of the stock of unemployed.

${ }^{6}$ This EU average figure hides considerable variation: for example, Germany has a ratio of about 1:200 and the Netherlands 1:60.

${ }^{7}$ High rates of registration often indicate that job seekers sign up with the national employment agency in hopes of securing public sector employment. Indeed, in some countries like Syria, Egypt, and Tunisia, registration with the national employment agency is a requirement for participation in the selection process for civil servants.

${ }^{8}$ As comparison, countries such as Latvia, Estonia, Slovenia, and Lithuania display higher jobseekers-to-vacancy ratio below 5 registered unemployed per one vacancy; while other in Eastern Europe and Central Asia display much higher jobseekers-to-vacancy ratio, ranging from 580 registered unemployed per one vacancy in Kosovo to 50 (24) registered unemployed per one vacancy in Armenia (Poland) (Kuddo 2009).

${ }^{9}$ Hard skills are the technical, mechanical, administrative, or other skills needed to do a specific job. Soft skills are the cluster of personality traits and interpersonal skills that help a person function effectively in the workplace, including social graces, language and communication abilities, amenability to training, ability to get along with other people, and ability to think creatively and independently.

${ }^{10}$ Prior to 2009 , employment guarantees were included in some training contracts financed by the Turkish National Employment Office, ISKUR. In-class training programs with employment guarantees displayed much higher job placement rates (54 percent) than similar programs without guarantees (33 percent) (see Betcherman et al. 2010).

\section{Additional file}

Additional file 1 Table A1. Literature Supporting the Proposed Policy Framework.

\section{Competing interests}

The IZA Journal of Labor Policy is committed to the IZA Guiding Principles of Research Integrity. The authors declare that they have observed these principles.

\section{Acknowledgement}

This study was prepared as a background paper for the regional study Building Effective Employment Programs for Unemployed Youth in the Middle East and North Africa, supported by the region's Chief Economist Office at the World Bank. The authors acknowledge support and valuable comments from Caroline Freund, Roberta Gatti, Yasser El-Gammal, Hana Brixi, David Robalino, Maria Laura Sanchez-Puerta, Theresa Jones, Arvo Kuddo, Saad Belghazi, Amina Semlali, May Wazzan, Anne Hilger, Diane Zovighian as well as from participants from the $7^{\text {th }}$ IZAWorld Bank Conference on Employment and Development held in New Delhi, India; November 5 to 7, 2012. The views expressed here are those of the authors and need not reflect those of the World Bank, its executive directors, or the countries they represent. We also thank our anonymous peer-reviews for their valuable inputs. Responsible editor: David Neumark

Received: 6 November 2012 Accepted: 6 August 2013

Published: 25 Sep 2013

\section{References}

Angel-Urdinola D, Semlali A (2010) Labor Markets and School-to-Work Transition in Egypt: Diagnostics, Constraints, and Policy Framework. MPRA Paper 27674, Munich Personal RePEc Archive. http://mpra.ub.uni-muenchen.de/27674 Angel-Urdinola D, Semlali A, Brodmann S (2010) Non-Public Provision of Active Labor Market Programs in ArabMediterranean Countries: An Inventory of Youth Programs. Social Protection Discussion Paper 1005. World Bank, Washington, DC

Angel-Urdinola D, Kuddo A, Semlali A (2013) Public Employment Agencies in the Middle East and North Africa. World Bank, Washington, DC

Belghazi S (2012) Evaluation Stratégique du Fonds National pour l'Emploi de la Tunisie. World Bank, Tunis, Tunisia Betcherman G, Olivas K, Dar A (2004) Impacts of Active Labor Market Programs: New Evidence from Evaluations with Particular Attention to Developing and Transition Countries. Social Protection Discussion Paper 0402. World Bank, Washington, DC 
Betcherman G, Gussing R, Jones P, Can R, Benus J (2010) Policy Note on Turkey's Active Labor Market Programs. World Bank, Washington, DC

Card D, Kluve J, Weber A (2010) Active Labor Market Policy Evaluations: A Meta Analysis. NBER Working Paper 16173. National Bureau of Economic Research, Cambridge, MA

Cho, Honorati (2012) Entrepreneurship Programs in Developing Countries: A Meta Regression Analysis. World Bank, Washington, DC

European Union (2009) Accreditation and Quality Assurance in Vocational Education and Training. European Centre for the Development of Vocational Training (CEDEFOP), Athens. 2009

Finn D (2011) Job Services Australia: design and implementation lessons for the British context. Research Report No 752. Department for Work and Pensions, London, United Kingdom

Gatti R, Angel-Urdinola DF, Silva J, Bodor A (2012) Striving for Better Jobs: The Challenge of Informality in the Middle East and North Africa. World Bank, Washington, DC

Graverson BK, Van Ours JC (2007) How to Help Unemployed Find Jobs Quickly: Experimental Evidence from a Mandatory Activation Program. Discussion Paper 6057. Centre for Economic Policy Research, London

Groh, et al. (2012) Soft Skills or Hard Cash? The Impact of Training and Wage Subsidy Programs on Female Youth Employment in Jordan. Policy Research Working Paper 6141. Impact Evaluation Series No. 62. World Bank, Washington, DC

Haddad M (2010) Short Term Effects of the Business Awareness Program of the Shahab Program. The Syria Trust for Development. PowerPoint presentation for World Bank workshop, Marseille. 2010

Hägglund P (2009) Effects of Intensified Employment Service Activities of the Swedish Public Employment Service: Experiences from Randomized Experiments. Report 2009:15. Institute for Labour Market Policy Evaluation, Uppsala, Sweden

Kuddo A (2009) Employment Services and Active Labor Market Programs in Eastern European and Central Asian Countries. Social Protection Discussion Paper 0918. World Bank, Washington, DC

Kuddo A (2012) Public Employment Services, and Activation Policies. Social Protection Discussion Paper 1215. World Bank, Washington, DC

Laguna M (2011) Chile's Monitoring and Evaluation System, 1994-2010. PREM notes: the Nuts \& Bolts of M\&E systems. World Bank, Washington, DC

Lahey R (2011) The Canadian Monitoring and Evaluation System. PREM notes: the Nuts \& Bolts of M\&E systems. World Bank, Washington, DC

Mackay K (2011) The Australian Government's Monitoring and Evaluation System. PREM notes: the Nuts \& Bolts of M\&E systems. World Bank, Washington, DC

Martinez S (2013) Vocational and Life Skills in Youth Training: A Randomized Experiment in the Dominican Republic. PowerPoint presentation for Human Development Week 2013, Human Development Network. World Bank, Washington, DC

OECD (Organisation for Economic Co-operation and Development) (2007) Employment Outlook 2007. OECD, Paris

Premand, et al. (2011) Entrepreneurship Training and Self-Employment among University Graduates: Evidence from a Randomized Trial in Tunisia. Policy Research Working Paper 6285. Impact Evaluation Series No. 77. World Bank, Washington, DC

Robalino DA, Rawlings L, Walker I (2012) Building Social Protection and Labor Systems: Concepts and Operational Implications. Background paper prepared for the Social Protection and Labor Strategy 2012-22. World Bank, Washington, DC

Rodriguez-Planas N (2007) What Works Best for Getting the Unemployed Back to Work: Employment Services or SmallBusiness Assistance Programmes? Evidence from Romania. Discussion Paper 3051. IZA, Bonn

Rodriguez-Planas N, Benus J (2010) Evaluating Active Labor Market Programs in Romania. Empirical Economics 38 (1):65-84

Schneider H (2008) The Labour Market Reform in Germany and Its Impact on Employment Services. In: Lilley P, Hartwich OM (ed) Paying for Success: How to Make Contracting Out Work in Employment Services. Policy Exchange, London, pp 49-58

Souktel (2013) Analysis and results produced specifically for this paper

Tergeist P, Grubb D (2006) Activation Strategies and the Performance of Employment Services in Germany, the Netherlands and the United Kingdom. OECD Social, Employment and Migration Working Paper 42. OECD, Paris

Tuck R (2007) National Qualifications Frameworks: Conceptual and Practical Issues for Policymakers. International Labor Organization. 2007

USAID (2007) Jordan Tourism Development Project - Siyaha. 2006-2007 Annual Report

World Bank (2012a) Reshaping Labor Markets through Technology. Background paper prepared for the Social Protection \& Labor South-South Learning Forum 2012. World Bank, Hyderabad, India

World Bank (2012a) World Development Report 2013: Jobs. World Bank, Washington, DC

World Bank (2013) Jobs for Shared Prosperity: Time for Action in the Middle East and North Africa. World Bank, Washington, DC

10.1186/2193-9004-2-13

Cite this article as: Angel-Urdinola and Leon-Solano: A reform agenda for improving the delivery of ALMPs in the MENA region. IZA Journal of Labor Policy 2013, 2:13 